\title{
The complementarity perspective to the entrepreneurial ecosystem taxonomy
}

Article

Accepted Version

Godley, A. ORCID: https://orcid.org/0000-0002-3160-2499, Morawetz, N. and Soga, L. ORCID: https://orcid.org/00000002-5471-9673 (2021) The complementarity perspective to the entrepreneurial ecosystem taxonomy. Small Business Economics, 56 (2). pp. 723-738. ISSN 0921-898X doi: https://doi.org/10.1007/s11187-019-00197-y Available at https://centaur.reading.ac.uk/86580/

It is advisable to refer to the publisher's version if you intend to cite from the work. See Guidance on citing.

Published version at: http://dx.doi.org/10.1007/s11187-019-00197-y

To link to this article DOI: http://dx.doi.org/10.1007/s11187-019-00197-y

Publisher: Springer

All outputs in CentAUR are protected by Intellectual Property Rights law, including copyright law. Copyright and IPR is retained by the creators or other copyright holders. Terms and conditions for use of this material are defined in the End User Agreement.

\section{www.reading.ac.uk/centaur}

\section{CentAUR}


Central Archive at the University of Reading

Reading's research outputs online 


\title{
The Complementarity Theory Perspective to the Entrepreneurial Ecosystem Taxonomy; The Case of Greater Reading Region.
}

\author{
Godley, A., Morawetz, N., Soga, L.,
}

\begin{abstract}
In recent years there has been increased interest in fast growing regions and the role played by entrepreneurship ecosystems (EEs) in regional economic development. Building on the entrepreneurship and economic geography literatures, we apply a complementarity theorybased approach to demonstrate that the elements of the EE taxonomy are not independent of each other but in fact are able to work as complementors to each other. The EE taxonomy is therefore a dynamic taxonomy. Very few non-metropolitan regions will possess all four elements of the EE taxonomy in significantly strong levels. So complementarity between the taxonomy elements within a region is crucial to supporting development for most EEs. We apply this complementarity perspective to the case of the Greater Reading region in the United Kingdom's Thames Valley. We expect the readership to extend beyond the academic community to policy and entrepreneurship practitioner audiences interested in supporting EE development.
\end{abstract}

\section{Introduction}

The explanation of the spatial concentration of economic activity is one of the most important achievements of the economics of agglomeration (Marshall, 1890; Saxenian, 1996; Armington \& Acs, 2002; Fujita et al., 2001). As a consequence of agglomeration economies in cities (Marshall, 1890), people were drawn to and inextricably bound together with other core business actors in close spatial, institutional and social proximity (Stam, 2007; Gertler, 2010). In recent years the entrepreneurial ecosystem (EE) has become a popular concept to explain why some cities grow and gain wealth and others stagnate (Isenberg, 2011; Mason \& Brown, 2014; Stam, 2015).

The EE approach builds on Marshall's legacy and re-awakens the 'new economic geography' or 'economy of a place' (Audretsch \& Feldman, 1996; Feldman \& Braunerhjelm, 2006; Audretsch et al., 2006, 2016; Buenstorf \& Fornahl, 2009; Audretsch, 2014). This approach shifts the focus from 'clusters' (with their benefits from local industrial specialisation, Porter, 2000 ) to knowledge spillovers across ecosystem actors, which result in broader economic benefits (van der Panne, 2004; Markusen, 1996).

Several ground-breaking studies have emphasized the importance of a systemic approach to EE (Acs et al. 2014; Borissenko \& Boschma, 2016; Spigel, 2017; Stam, 2015; O' Connor et al., 2018), and this has been rapidly adopted in the literature. This has recently led to the development of a taxonomy of EEs by Mason and Brown (2017). While there are great advantages to having a systemic concept and a single taxonomy, the literature has tended to overlook the sheer heterogeneity of EEs. There are significant limitations to the single taxonomy. First, like any taxonomy, the EE taxonomy lacks explanatory power. Second, it is not clear what entrepreneurial and regional development strategies need to be applied to those heterogeneous EEs (Isenberg \& Onyemah, 2016) where some EE taxonomy elements remain relatively weak. Third, the network perspective (which is often used to analyse ecosystems, Kemeny et al., 2015; Spigel, 2017) does not actually explain how EEs function.

Entrepreneurial actors within any EE are not necessarily connected to each other (Szerb et al., 
2013). Weak and strong ties between ecosystem actors (Granovetter, 1973) may or may not support the EE economic success.

This study therefore aims to show that the EE taxonomy is a dynamic taxonomy, more than a simple and static classification of all the elements of an EE. In particular, by developing a complementarity perspective (Wu et al., 2014; Williamson \& De Meyer, 2012; Adner \& Kapoor, 2010) and applying it to the EE taxonomy, we propose a mechanism to explain how regions which lack strength in one or more dimensions of the EE taxonomy can still be successful in supporting and developing local EEs.

We also show how this applies to the Greater Reading region in the United Kingdom. Reading is an example of a highly successful EE located in the Thames Valley, outside the metropolitan centre of London. We argue that Reading, along with other examples of successful European EEs located outside large metropolitan centres (such as Augsburg, Utrecht, Rotterdam, Hamburg, Bergamo, Torino, Milan, and so on), should become a model of regional economic development for non-metropolitan cities, where exploitation, rather than exploration, of knowledge is the main competitive advantage (Porter, 2000; Saxenian, 1996).

This study contributes to economic geography, entrepreneurship and small business literatures by combining all four dimensions of Mason and Brown's (2017) taxonomy with the complementarity concept (Beckman et al., 2004; Nambisan \& Baron, 2013; Wu et al., 2014) to explain how complementarities contribute to the entrepreneur's performance (O'Connor et al., 2018). This study is particularly important for EE research, which aims to understand how ecosystem actors exploit existing capabilities rather than engaging in exploration activity (Kirzner, 1999). The complementarity theory perspective has been used in industrial economics and in management (Pierce, 2009; Lee et al. 2010). But its application in EE literature has so far been limited (Spigel, 2017; Stangler \& Bell-Masterson, 2015; Stam \& Spigel, 2016; O’Connor et al., 2018).

More theoretical and empirical work is urgently needed to better explain how various combinations of the EE taxonomy may produce productive outcomes. Applying the complementarity concept in our case highlights that the elements of the ecosystem taxonomy interact with each other, and, importantly, can even substitute for one another. An understanding is needed about what function the elements of the EE are intended to perform and how well these elements in different combinations contribute to the expected outcome (Clarysse et al., 2014). This study makes the following four contributions to the EE and economic geography literatures. First, it offers an in-depth analysis of the complementarity perspective to explain the potential interconnectedness between the separate elements of the EE taxonomy. Second, we emphasize why it is important to treat the EE as a unit of analysis in the geography of entrepreneurship (Audretsch \& Belitski, 2017; Stam, 2018). Third, we debate the mechanisms and conditions that enable the elements of the EE taxonomy to interact in a mode similar to networks. Fourth, the example of the Greater Reading EE shows how some taxonomy elements have combined to overcome the disadvantages of weaker elements to produce a dynamic and strong EE with a particular emphasis on knowledge exploitation.

The next section describes existing literatures and theories and introduces the complementarity approach to the EE taxonomy. Section 3 presents the case of the Greater Reading region. Section 4 applies the EE taxonomy to this region. Section 5 discusses the 
major pillars of the Reading EE and the role of complementarities in building stronger ecosystems. Section 6 concludes with the article's major contributions, limitations and suggestions for further research.

\section{Theoretical Framework}

\subsection{Entrepreneurship Ecosystem Taxonomy}

The concept of the EE has evolved rapidly in the last few years. It has contributed towards helping researchers and policy-makers think in systemic terms when considering the entrepreneurial activity of regions and countries. As a new unit of analysis, the EE contributes to providing a more realistic portrayal of the entrepreneurial phenomenon, and allows researchers to take a much broader perspective when considering the role that each economic actor plays (Audretsch et al., 2006). The majority of observers view ecosystems primarily as a spatial concept (Feldman \& Braunerhjelm, 2006; Mason \& Brown, 2014, 2017; Audretsch \& Belitski, 2017) to explain why certain places have higher levels of entrepreneurial activity (Feldman, 2014; Spigel, 2017). Entrepreneurship, not innovation, is the fundamental driver behind the concept. In this paper we view EEs through this lens. Mason and Brown (2014) set out a definition of EEs as a 'set of interconnected entrepreneurial actors, entrepreneurial organizations, institutions and entrepreneurial processes which formally and informally coalesce to connect, mediate and govern the performance within the local entrepreneurial environment' (Mason \& Brown, 2014, p.5). Clearly, the dynamic and systemic nature of the concept encompasses multiple actors, institutions, industries and processes.

Various scholars have attempted to explore and interpret EEs with respect to multi-actor networks, and the pre-conditions of EE success. But it is the fusion of diverse perspectives which has proved to be the strongest asset (Mason \& Brown, 2017). At the same time, this fusion of diverse perspectives to EEs and their hybrid nature makes measurement of EE extremely complex (Stangler \& Bell-Masterson, 2015; Isenberg and Onyemah, 2016; Audretsch \& Belitski, 2017; Stam, 2018). Case studies have remained one of the most comprehensive ways to research the genesis of heterogeneous EEs in their local contexts (Best, 2015; de Villiers Scheepers et al., 2018; Sussan et al. 2018).

Mason and Brown (2017) recently developed the important Entrepreneurship Ecosystem taxonomy. They specify four main coordinating elements. The first element is Entrepreneurial Actors. They are at the heart of the ecosystem concept (Isenberg, 2011; Mason \& Brown, 2014; Stam, 2015). Whereas the systemic innovation literature portrays entrepreneurship as something of a 'black box' (Stam, 2015), entrepreneurs and the supporting entrepreneurial infrastructure are the core actors within the EE concept (Isenberg, 2011; Mason \& Brown, 2014, 2017; Stam, 2015).

The second element is Entrepreneurial Resource Providers. These underpin the workings of the EE and enable the transfusion of resources into firms. Finance is a fundamental resource for start-ups and growth-oriented innovative firms (Lee, 2014) and for knowledge transfer (Audretsch et al. 2016). Financial providers include banks, venture capital firms and business angels and other financial institutions. Accelerators are also an important resource provider designed to support growth-oriented ventures (Miller \& Bound, 2011; Clarysse et al., 2014, 2015). 
The third element is Entrepreneurial Connectors. Networks are crucial for nascent ventures (Granovetter, 1973; Brüderl \& Preisendörfer, 1998). Dynamic EEs typically have strong informal and formal networks, which help alleviate resource deficiencies in start-ups and facilitate tacit knowledge sharing (Sullivan \& Ford, 2014). EEs feature a number of different networking opportunities, such as business clubs and mentoring opportunities (Spigel, 2017) which act as the communal lifeblood of the ecosystem and add to the region's social capital (Malecki, 2012).

The final and fourth element is Entrepreneurial Orientation. This represents societal norms and attitudes which support entrepreneurship activity (Isenberg, 2011). Mason and Brown (2017) refer to Feld's (2012) study of entrepreneurship in Boulder, Colorado, which stressed the importance of an inclusive and supportive entrepreneurial culture as a key factor in that region's success. Entrepreneurial aspirations and the creation of an entrepreneurial identity associated with a specific place are vitally important components of local culture that enhance the entrepreneurial orientation of a city (Feldman, 2014). Despite efforts to change cultural attitudes towards entrepreneurship, most government initiatives have struggled to improve entrepreneurial orientation (Van Stel \& Storey, 2004; Brown \& Mason, 2013).

\subsection{The Complementarity Approach to the Entrepreneurship Ecosystem Taxonomy}

Given the ability of entrepreneurs to achieve complex tasks with limited resources (De Massis et al. 2017), scholars have tried to understand how the external business environment can better assist entrepreneurs (O'Connor et al. 2018; Spigel, 2017). This has spawned the related concepts of: clusters, industrial districts, innovation ecosystems, networks and innovation systems, as well as EEs. EEs are an inherently geographic concept, they focus on multiple actors, cultures, institutions and networks that build up within a region over time (Mason \& Brown, 2014). These relational networks are a set of interdependent actors coordinated in such a way that they enable productive entrepreneurship within a particular territory (Stam \& Spigel, 2016). Building on the importance of interactions and relational networks between the EE actors, Mason and Brown (2017) define an EE as a set of interconnected stakeholders, such as venture capitalists, business angels, banks, universities, public sector agencies, corporations, local and national government and entrepreneurs themselves (Isenberg, 2011; Mason \& Brown, 2014; Brown \& Mason, 2014).

This approach to understanding an EE recognises that a firm can no longer satisfy market demand by drawing on the dynamic "knowledge and capabilities of just a few, large-scale specialist units" (Williamson \& De Meyer 2012, p.24). Complementarity between interconnected stakeholders is of particular importance in an EE, because an entrepreneur relies on the external business environment to achieve his/her complex tasks with limited resources (De Massis et al., 2017). There are resources outside the boundaries of an entrepreneurial firm that can contribute to its competitiveness. Equally, other stakeholders (such as larger firms, suppliers and customers, local government, private investors, etc.) within the EE are able to benefit from engaging with entrepreneurial actors and gain access to their resources. Lee et al. (2010) define this sort of complementarity as a relatively stable relationship, which allows firms to "gain competitive advantages through the assets of another firm" (Lee et al., 2010, p.1433).

As well as this emphasis on collaboration among stakeholders, EEs are also subject to competition forcing improvements in performance. According to Pierce (2009), "While 
individual stakeholders in [this] ecosystem may seek personal gain, the competitive environment selects out those firms that hurt the community's economic health" (Pierce, 2009, p.325).

Changes in the external environment affect performance of entrepreneurs and an EE as a whole, and may be exogenous - coming from regulatory, technological, institutional, social or other contexts. But they may also be prompted by the actions of EE stakeholders, whose strategies and decisions can greatly impact other stakeholders (Pierce 2009). The activities of ecosystem stakeholders then influence the degree of complementarity between the elements of the ecosystem. Changes in one element may enable or inhibit performance of other elements. The factors that alter the degree of complementarity and those that may affect performance of an EE are captured by the EE taxonomy (Mason \& Brown, 2017).

The contribution of each element of the taxonomy to EE performance therefore depends on how effectively it complements other elements, by facilitating competitive responses to exogenous and endogenous shocks. Hence, the success of EE depends on its efficiency allowing each element of the ecosystem to build on the others. Complementarities were described as a key to the successful use of performance measurement systems (Wu et al., 2014) and the entrepreneurial ecosystems (Pierce, 2009; Stangler \& Bell-Masterson 2015; Audretsch \& Belitski, 2017). Complementarities change the way ecosystem stakeholders use the ecosystem resources in managing and leveraging the performance of an $\mathrm{EE}$ as a whole.

In applying the complementarity perspective to the EE taxonomy, we draw on the concepts underpinning EE performance (Stangler \& Bell-Masterson, 2015), the importance of the context for entrepreneurs (Porter \& Siggelkow, 2008; Acs et al., 2014; Autio \& Thomas, 2014; Stam, 2015) and the complementarity concept in the business environment (Porter \& Siggelkow, 2008; Pierce, 2009; Lee et al., 2010; Welter et al., 2017). Some scholars argue that the performance of the EE is critically dependent on behavioral, cultural and institutional factors (Qian et al., 2013; Acs et al., 2014; Spigel, 2017) including the ability of ecosystem stakeholders to explore and exploit with a certain degree of complementarity (March, 1991; Beckman et al., 2004). Others argue that performance is the result of the interplay between various elements of EE's taxonomy (Mason \& Brown, 2014, 2017), such as the Triple Helix Model where interactions between university, government and industry enable innovation and knowledge transfer between ecosystem actors (Etzkowitz \& Leydesdorff, 2000).

Arguments about the roles played by the external business environment and ecosystem actors in the performance of an EE guided us in developing a theoretical concept, which should embrace all elements of taxonomy as separate but interdependent dimensions. These elements are linked, either directly or indirectly, and jointly inhibit or enhance the performance of the ecosystem. There are three propositions that underpin this thinking:

First, any change to the EE taxonomy elements encouraging greater participation in and sharing of complementarities among the ecosystem actors is likely to change the other elements in the taxonomy. This proposition is based on Mason and Brown's (2017) assertion that entrepreneurial resource providers and actors on the one hand and entrepreneurial connectors and orientation on the other hand are separate but interdependent. We deduce therefore that change in one is likely to result in change in the other.

Second, any change to the taxonomy elements designed to enhance complementarities among the ecosystem actors is likely to alter performance of entrepreneurs and an EE as a whole. 
The effect is both direct, as each dimension affects the EE performance overall, and indirect, as improvement in the EE performance is moderated by the degree of complementarity between the ecosystems actors.

Third, complementarities do not happen automatically. There must be some institutional mechanism within an EE which identify where the region's ecosystem may be relatively weak and is then able to co-ordinate a response by drawing on the stronger elements within the EE.

Why should these three propositions hold? Literature on complementarities and performance measurement (Pierce, 2009; Liu et al., 2014) indirectly suggests a direct relationship between higher levels of EE and entrepreneurial actor performance (Mason \& Brown, 2017), and an indirect relationship via complementarities (Choi et al., 2008; Wu et al., 2014). It also suggests that an entrepreneurial actor can be more successful when all entrepreneurship ecosystem actors work cooperatively with each other contributing to the overall performance of an entrepreneurial ecosystem (Bengtsson \& Kock, 2000). The indirect effect manifests itself through the incomplete excludability of knowledge and technology (Arrow, 1969; Audretsch et al., 2016). Arrow (1969) showed that positive externalities flow to all actors involved with new knowledge creation because of the non-exclusive and non-rivalrous nature of information.

There are two channels of complementarities in the entrepreneurship ecosystem. First, no entrepreneurial actor can appropriate completely the technology and knowledge they create. So new knowledge spills over to the other ecosystem actors. Second, firms work cooperatively within an ecosystem. So the performance of each actor may depend on performance of the other actors and on the ecosystem as a whole (Bengtsson \& Kock, 2000). Externalities arising from information sharing and knowledge diffusion among the entrepreneurial connectors (networks) and the entrepreneurial resource providers (finance and service providers) within the ecosystem facilitates entrepreneur's activity and adds to overall EE performance (Audretsch et al., 2016). The asset of new knowledge for one ecosystem actor becomes a complementary asset to a third party within the ecosystem (Lee et al., 2010).

But, third, because of the difficulty of pricing new knowledge (Arrow, 1969), any EE will have a tendency to market failure. Understanding the correct price for external assets will be difficult, requiring significant entrepreneurial judgment (Casson, 1982, Alvarez et al., 2014; Casson \& Godley, 2015). It follows that if one element within the EE is relatively weak or in short supply, its relative scarcity may not drive up its price and so may not permit the automatic adjustment present in functioning markets. For the elements in EEs to function as complementors to one another, there must be some actor able to co-ordinate or to facilitate the coordination of the the complementary response.

In sum, incorporating the complementarity concept suggests that each entrepreneurial ecosystem's performance depends not only on how effectively it embodies all four elements of the EE taxonomy, but also on how effectively complementarities are exploited. First, the EE performance depends on how effectively the elements are each able to compensate for weaker elements. Second, agency among EE stakeholders means some individuals or organisations are able to co-ordinate a response to draw on existing EE strengths and to overcome weaknesses in the EE elements, enabling EE performance overall to increase. 


\section{The Case of the Greater Reading Entrepreneurial Ecosystem}

Within the broad Thames Valley region to the west of London, Reading (historically the county town of Berkshire) has emerged as a thriving urban area of over 320,000 people and is the dominant commercial centre (The Business Magazine, 2017). Reading has thus emerged as an important centre to compete with London as a commuter destination in the South-East of England (Centre for Cities, 2017). It has become the approximate regional capital city of the wider Thames Valley economy (Centre for Cities, 2017). Along with the immediately adjacent towns of Wokingham, Bracknell, Slough and Newbury, the Greater Reading region has a population around one million and stretches for about 40 miles westwards along the M4 corridor west of Greater London. Historically, the Thames Valley economy has benefitted from its relative proximity to London and Heathrow airport. These locational advantages have attracted many foreign businesses to locate there. Over a quarter of all workers are employed by foreign-owned businesses in Reading, making it the city with the highest concentration of foreign-owned businesses in the UK by some distance (TVB, 2014).

While the Thames Valley region overall has experienced significant economic growth, the nature of that growth varies somewhat across the region. First, as is the case elsewhere in the UK, cities are growing faster than the surrounding towns. Oxford's economy is very much driven by its traditional universities focused on exploration of knowledge, and early-stage spin-outs. Slough's economy has benefited from very rapid immigration and corporate expansion. Reading, by contrast, has become the commercial centre of the region and UK's leading city for IT technology outside London, and it is very much focused on the exploitation of knowledge created elsewhere, with its private sector employment dwarfing the rest of the Thames Valley (see Centre for Cities, 2017, p.47).

Recent rankings of the UK's most successful tech firms continue to be dominated by London-based firms. But Reading has become the undisputed second region in the UK tech industry after London. KPMG Tech Monitor has repeatedly placed Reading as the top technology cluster in the UK. Indeed, if KPMG used the same geographic unit as either Demos or the Office for National Statistics (ONS), then the gap between Reading and any other comparable region in the relative concentration in the technology sector in the UK would become even more apparent, as the KPMG survey ranks Wokingham second, Slough third and Bracknell Forest seventh - all three towns are immediately adjacent to Reading and part of the Greater Reading region (KPMG, 2015).

It is important to note that for overall economic performance it is not the number of start-ups that matters but the proportion that go on to grow quickly. Only a tiny minority of new companies grow quickly, only $1 \%$ nationally. It is these firms that contribute disproportionately to job creation. What marks Reading out as distinctive is the concentration of these successful start-ups and entrepreneurial firms within the region. With $5.5 \%$ of all businesses in the region being high growth small businesses, there is a far greater concentration of high-growth start-ups than anywhere else. Octopus Investments' tracking of High Growth Small Businesses (with a slightly different definition) has identified Reading as the top location in the UK for fast growth SMEs since 2015. Only the far more populous cities of London and Birmingham have a higher absolute number (Rogerson, 2016). The Scale-Up Institute also concluded that Reading had the greatest absolute number of scale-ups outside London. 


\section{Understanding the Greater Reading Region Using the Entrepreneurship Ecosystem Taxonomy}

In order to gain a deeper understanding into the Greater Reading region and by consequence, the complementarity of its EE elements, we approached this study with an interpretivist lens. We felt that to understand the Greater Reading region, we needed to allow the participants to speak for themselves; here, their subjective evaluation of the region with respect to their businesses was necessary for our understanding. Furthermore, this approach allowed us to exploit our own expertise within the Greater Reading region as well as our access to and understanding of Thames Valley/Berkshire-specific documents obtained for this study. For this research, we identified and interviewed eleven representative scale-ups in the Thames Valley area. First, we chose scale-ups and not start-ups because with scale-ups, we could be sure that these businesses were among the very small minority of high-growth small firms. Second, our selection of interviewees was done with purposive sampling logic, which is a purposeful selection of participants based on their unique characteristics that can "inform an understanding of the research problem and central phenomenon in the study" (Creswell, 2007, p.125). This allowed us to stay within the study's objectives by targeting only scale-ups within the region that we have gained access to. Third, by targeting scale-ups, we obtained primary data from those that have been in the region long enough to see themselves as part of its EE. Their longevity in the region permitted greater insight into its history, development, ecosystem, and how they partook of its EE elements. To stay within the objectives of the study, we used the four EE taxonomy elements deductively as the lens through which we constructed meaning. Within that, our analytic process involved making sense of the large amounts of data we had access to (Denzin \& Lincoln, 2005), in what Cousin (2007) describes as "thinking with data". This thinking with the data led us to develop themes that emerged for our discussion as we theorized. To maintain originality of thought, we provide verbatim quotes from interviewees which directly speak to the EE elements and which also justify the analytic evaluations we made in the study (Corden \& Sainsbury, 2005). These direct quotes are provided within the ethical framework of consent and confidentiality, except in those cases where the interviewee has granted permission for their identities to be revealed.

\subsection{Entrepreneurial Actors.}

Reading has long been a centre for start-ups. There have always been entrepreneurs present. But in Mason and Brown's taxonomy, EE success follows from the example of particularly influential individual entrepreneurs who act as role models for others. The history of Silicon Valley, for instance, revolves around several key individuals, such as David Packard, Robert Noyce and Steve Jobs. The emergence of Cambridge as a technology-focused EE is strongly associated with Herman Hauser, one of the founders of Acorn Computer and Amadeus, who played a crucial role in the development of Cambridge as a high-tech region (Garnsey \& Heffernan, 2005). The Greater Reading region lacks such influential figures from its recent business history. In earlier times, Reading was a centre for agriculture and food processing, leading to a world-renowned biscuit manufacturing company, Huntley and Palmers, the founding family of which played a key role in the development of Reading as an industrial cluster in the early part of the twentieth century. But the recent emergence of the Greater Reading region as a technology-focused EE is not associated with its history in the food sector. Most entrepreneurial activity within the Greater Reading EE occurs in the IT and digital media sectors, described aptly by a study participant as "leaning towards tech entrepreneurship" (TB, 690-2018). This owes its origins to a series of major investments by 
large and mostly foreign technology companies, beginning in the 1970s with ICL and Digital Equipment Corporation, followed by software companies, such as Microsoft, Oracle and others opening their European headquarters in the Thames Valley in the 1990s, before being followed by the telecoms sector, with firms ranging from Vodafone, to Orange, EE and Huawei all having their UK headquarters (HQs) within the EE (Centre for Cities, 2017). These UK HQs (mostly of subsidiaries of overseas MNEs) of large corporations in the IT, telecoms and related sectors were not important entrepreneurial actors. But they did act as an attractor for highly skilled individuals "so when we're looking to grow and recruit additional people there is a ready supply of candidates with good technical skills" as mentioned by a research participant (JW, 677-2018).

Important entrepreneurial actors in the Greater Reading region are the locally well-known Scale ups (Isenberg \& Onyemah, 2016). Napier and Hansen (2011) and Mason and Brown (2014) call them the 'blockbuster entrepreneurs or 'breakout companies' (WEF, 2014). Scale ups are young fast-growing entrepreneurial firms that have evolved exceptionally in size and speed. Isenberg (2010) and Napier and Hansen (2011) contend that the case of scale-ups is exceptional. As role models they spread entrepreneurial success through spillover effects to large incumbent firms, fast-growing SMEs and individual entrepreneurs, usually bringing together all EE stakeholders - entrepreneurs, angel investors, venture capitalists, board members, advisors and mentors (Feldman \& Braunerhjelm, 2006). Important tech-sector Scale-ups in the Greater Reading region since 2016 or 2017 have become very prominent and would include Datasift and Fairsail, among others. While these very recent examples are currently important Entrepreneurial Actors, Reading as a region has not had a strong history of possessing role model entrepreneurial actors. An interviewee confirms that "as far as other role models are concerned, I'm not aware of any particularly," (RD, 936-2018). This seeming absence of role models does not, however, belie the fact that the Thames Valley boasts itself of hosting many technology entrepreneurial firms that also have presence across the globe.

\subsection{Entrepreneurial resource providers}

Reading is closely connected with London and has a number of financial channels for entrepreneurs to explore. Along with debt financing, accelerators are important sources of finance of EE in Reading and provide additional support to businesses. Accelerators, or so called 'startup factories' (Miller \& Bound, 2011), have grown very rapidly in recent years in large metropolitan centres such as London, Chicago and Berlin (e.g. Y Combinator, Rocket Internet, Barclays Techstars, Innovation Warehouse, Funlab, Wayra). The Start-up Grid incubator for business located in one of three international business parks in Reading has brought accelerator culture to Reading. We observe various hybrid forms of incubation such as incubators run by various actors who combine different functions (e.g. the strong mentoring and training role of the Henley Business Angels, the research and exploitation of knowledge in the University of Reading Science Park). Reading remains a relatively small EE but with a rapidly developing entrepreneurial infrastructure. The dynamics of this ecosystem is different and unfortunately largely ignored by researchers (Clarysse et al., 2015). These various hybrid incubators are helping to bolster a large number of high-growth start-ups and scale-ups. Here, Mr. Jurek Sikorski, who is Executive Director of the Henley Centre for Entrepreneurship, clarifies that "it is not just the physical incubator infrastructure but also the intellectual support, business mentoring, and collegial atmosphere these incubators offer that make them attractive for start-ups". However, other resource providers like venture capitalists, banks, angel investors (except a few like the Henley Business Angels) are not immediately accessible within the Greater Reading region as "most of the 
negotiations with the private equity firms or even private investors themselves, would be done in London" (JW, 677-2018).

\subsection{Entrepreneurial Connectors}

What definitely defines Greater Reading ecosystem is its spatial boundaries (Feldman \& Braunerhjelm, 2006; Feldman, 2014). Close geographic proximity of entrepreneurs to each other follows a spatial logic, which boosts network formation and knowledge exchange as argued by Mason and Brown (2017). Greater Reading Ecosystem is characterised by more complex 'nested geography' when its EE is embedded within the larger region of South East England, in between Oxford and London, and so involves multi-scalar interactions with entrepreneurial actors in both cities. A growing number of multinationals in Greater Reading brings domestic and international networks to the city.

The Greater Reading region clearly benefits from its geographical connectedness to London, so entrepreneurial actors enjoy frequent and easy access to interactions with nonlocal parties. Study participants reported on how they considered their location's influence on their businesses by stating access to London as one positive advantage for being within the Greater Reading region. Examples include, "I guess a fondness, or an ease of working within the county. In terms of my own business, though. I think, for me, it's access to London" $(\mathrm{CH}$, 839-2018); "London is very expensive, so the Thames Valley is the next best option for a region, because it's still close to the capital, but at the same time it's more affordable, both for business and for people to live" (RD, 936-2018); "We were deliberately positioned here because the two main hubs prior to us taking on the lead were London and Oxford, and obviously we were ideally positioned between the two. So most of my network comes from that or one in London" (TB, 877-2018).

Additionally, the Brittelstand network run by Henley Business School (mimicking the worldrenowned German Mittelstand company concept) is deeply embedded into the Reading EE with close connections to regionalised banks, schools, local government and research centres (Audretsch \& Lehmann, 2016; De Massis et al., 2017; Mason \& Brown, 2017). These activities contribute to the overall 'local buzz' (Bathelt et al., 2004), similar to the concept of industrial clustering (Buenstorf \& Fornahl, 2009) which creates the information and communication environment for all EE actors, in particular incumbents and scale-ups to enable face-to-face interactions, co-location of people and firms within the same area (Stam, 2007; Bathelt et al., 2004). The Greater Reading EE consists of continuous updates of the information for business via university and business school events, newsletters and incubation programmes, which lead to planned and spontaneous meetings, the mutual understanding of new knowledge and technologies, as well as shared cultural traditions and habits within a particular technology field (Gertler, 2003; Stam, 2015; Mason \& Brown, 2017). Although financial resource providers are genereally hard to access (as expressed in the previous section), availability of "dealmakers" in Greater Reading such as incubators, coworking spaces in techno-parks and a few angel investor networks act the role of mediating relationships, facilitating new businesses to enter or funding existing ones to scale up (Feldman \& Zoller, 2012).

\subsection{Entrepreneurial orientation}


The EE is an inherently dynamic concept, which acknowledges the importance of entrepreneurial processes and cognitive belief systems. In the Greater Reading region the crucial aspect of ecosystems are the scale-up firms with a moderate support from other EE stakeholders. There is considerable evidence which shows that large incumbent firms in IT sector such as Vodafone, Huawei, Microsoft and Oracle have played a central role in configuring a corporate or business ecosystem (Mayer, 2013), but not an entrepreneurship ecosystem (Mason \& Brown, 2017; O'Connor et al., 2018).

Over time incumbent large firms worked as attractors of skilled labour and as customers for entrepreneurial firms. This had a mini-incubation effect on entrepreneurs, generating considerable knowledge spill-overs (Arrow, 1969; Eliasson, 2000) and co-location and relocation to Greater Reading of incumbent firms (Saxenian, 1996). This has triggered the development of localised skills and competences (Porter, 2000; Delgado et al., 2010), in particular in the software sector, thus impacting the emerging 'entrepreneurial culture', as discussed in Mason and Brown (2017). The study participants compared the entrepreneurial identity of the Greater Reading region to a large extent to Silicon Valley; "I would say it's probably very similar. People do call it the Silicon Valley of the UK, the Thames Valley" (JJ, 677-2018)

These large incumbents recruited and trained many people, some of whom went on to found successful businesses. The casual inference is that the local area has gained through an accumulation of local skill levels arising from previous inward investments, as these individuals have then created their own businesses, prompting the growth of the clustering of the regional economy (Klepper, 2010).

Undoubtedly the biggest single weakness to this emergent Entrepreneurial orientation in Greater Reading is the lack of a clear identity (Centre for Cities, 2017). Example, a study participant states that "we are more conservative here in the Thames Valley versus Silicon Valley" (TB, 690-2018). We concluded that, this lack of clarity regarding Greater Reading's entrepreneurial orientation offers an avenue for future research, in which other nonentrepreneurial actor EE participants would present a more balanced view, instead of data obtained from only scale-up entrepreneurs, who aspire to be similar to successful entrepreneurs and well-established EEs elsewhere, like Silicon Valley.

However, we felt that without any clear self-identity as a centre for entrepreneurship, the local entrepreneurial orientation will always be less developed than it could otherwise be. Local public and business agencies delivering on the Thames Valley Berkshire Local Economic Partnership Strategic Plan also refer to this seeming inability to 'get the message out' to all stakeholders of the entrepreneurial ecosystem (The Business Magazine, 2017). We thus argue that this element of EE taxonomy has remained weak, undermined by weak and fragmented local political structures and a lack of any coherent strategic vision for the region. Entrepreneurial culture evidently exists, the data relating to the region's exceptional performance confirm that. But with its complex geography, the spatial boundaries of the Greater Reading entrepreneurial ecosystem are not easily recognised. The wider Thames Valley is recognised locally as the regional unit. But this region is bigger and substantially more diverse than the Greater Reading region, and so any recognition of Reading's remarkable performance and distinctive features is substantially diluted. Without any obvious regional identity, the entrepreneurial character of the place struggles to be celebrated (Feldman, 2014). Local inhabitants remain unaware of the region's strength as an EE. This is 
reinforced by the relative absence of role model entrepreneurial actors (Isenberg, 2011), which we also find in this study (see Section 4.1).

\section{Discussion}

We believe that each element of the taxonomy is important for EE development. But by introducing the complementarity theory perspective, we argue that success of an entrepreneurial ecosystem is influenced not only by the performance of each four elements of EE's taxonomy (Mason \& Brown, 2017) but also by the elements' complementarity and interdependence. Based on a review of the ecosystems literature to date, we mapped the interplay between four elements and discussed the importance of complementarities in the entrepreneurial ecosystem taxonomy framework. We derived three key propositions that typify the complementarity framework. Further discussion is structured around the Greater Reading region case study.

The Greater Reading EE is currently following a similar development path seen earlier in the Greater Boston EE (Best, 2015). This is to transition to a high-tech, open-system business model with corporate culture, entrepreneurial connectors and actors all focused on the adaptation and exploitation of new knowledge. But Reading is doing this in the relative absence of a strong entrepreneurial orientation or of any powerful local role model entrepreneurial actors (Feldman, 2014). Instead, Reading has compensated for its weakness in entrepreneurial orientation by developing its EE through a greater emphasis on its entrepreneurial connectors and key resource providers supported by the world-class placebased infrastructure and a regional strength in the ICT sector (Eliasson, 2000). Furthermore, the lack of prominent entrepreneurial actors was compensated for by leveraging the advantage of a high concentration of local entrepreneurial resource providers, in particular private $R \& D$ resources from the incumbent MNEs, local entrepreneurship hubs and incubators as well as venture capital in close proximity (often in London).

The core complementarities which were the most important pillars to Greater Reading's EE success story can be listed as: the role of focal firms, close proximity to specialised contractual infrastructure, the impact of the local University Business School, and the distinctive global focus. We discuss each in turn.

\subsection{Focal firms}

We have already mentioned the importance of a series of major investments by large and mostly foreign technology companies, beginning in the 1970s, but accelerating in the 1990s and 2000s, leading to a regional specialisation in telecoms and IT (Centre for Cities, 2017). These large employers recruited and trained many people, some of whom went on to found successful businesses. Overall, half-a-dozen software giants employ more than twenty percent of Reading's working population (Anderson, 2015). The ecosystem's complementarities very much involve collaboration with suppliers and customers in software industry. The casual inference is that the local area has gained through an accumulation of local skill levels arising from previous inward investments as these individuals have then created their own businesses, resulting in the clusterisation of the regional economy (Bathelt et al., 2004; Klepper, 2010).

\subsection{Contractual infrastructure and IT-enabled support}


Entrepreneurs are the key stakeholder of an EE, but they require specialised support services and infrastructure to succeed (Leten et al., 2013). So here the proximity to specialised business infrastructure as well as commercial support services (often based in London) has strongly benefited Reading's entrepreneurs compared with other regional centres in the UK. This can be described as a local 'contractual' infrastructure, because it is this collection of services and expertise that first, enables the identification of a financial value of the emerging business and second, provides necessary expertise to market products and services. Specialist expertise lies in the areas of: identifying and claiming intellectual property rights, in valuation, in specialist forms of financing, in allocating rights (especially for the burgeoning digital publishing sector), in identifying suitable partners for development and commercialization, for access to specialised markets, and specialists able to pull all of this complexity together into contracts that facilitate the flow of resource. The significance of such a local contractual infrastructure is particularly relevant to the technology and IT sector over the past ten years, because attributing credible value to business models has been particularly complex. As financial conditions have eased increasingly since 2011, so risk appetite has increased and investors have been increasingly willing to invest. For techfocused entrepreneurs in the Reading region, easier access to cutting-edge financial metrics from innovative accountants and lawyers has made the difference between investment funds received or not, or between the amount that is adequate for fast growth or not.

\subsection{Henley Business School and the University of Reading: entrepreneurship support actors}

Henley Business School and the wider University of Reading play a key role in the Greater Reading EE in a number of ways. First, the University is the principal provider of highly skilled workers in the region, with student numbers increasing rapidly year on year, and around 20 percent of the University's graduates remaining in the region. This is a near doubling of the supply of skilled graduates to local recruiters in five years. Furthermore, the skills with which University of Reading students are leaving with are changing as well, with a much greater focus on being business-ready on graduation. For example, the number of University students that have taken some Henley Business School credit-bearing content on entrepreneurship during their degree programme has increased more than five-fold since 2010 (HCFE, 2017). Second, the university is a key ecosystem stakeholder with regards to new knowledge creation and its commercialization, through university-industry partnerships and knowledge transfer partnerships (KTP). Third, the university encourages co-location of tech-intensive companies on campus and within its science parks.

However, what seems to have been far more influential in the recent emergence of such a successful EE in the Reading region is the role played by Henley Business School. Henley is one of the world's leading triple-accredited business schools, with a historic focus on executive education among large corporates and MBA teaching for those wanting to work in large corporates. Although it was not a pioneer in supporting entrepreneurship, the Henley Centre for Entrepreneurship (within Henley Business School) has however developed a role as a focal institution for the region's entrepreneurs. It offers regular networking and training events, it is the leading source of mentoring and coaching for entrepreneurs, and has developed the successful Henley Business Angels to provide seed funding and mentoring to high potential early stage ventures in the region.

The Greater Reading EE possesses abundant Entrepreneurial resource providers and Entrepreneurial connectors, but has been relatively weak in Entrepreneurial orientation and in prominent entrepreneurial actors. One feature which needs to be emphasised in stimulating 
the complementarity of the stronger taxonomy elements to compensate for the weaker ones is the crucial role of an entrepreneurial community (Audretsch, 2014). Entrepreneurial communities within geographical boundaries are likely to foster knowledge spillover of entrepreneurship by connecting entrepreneurs with resource providers and introduce entrepreneurial actors to available technologies at universities and incumbent firms. And so accelerate the compensatory actions of complementors. In the Greater Reading region, Henley Business School and its Henley Centre for Entrepreneurship have developed the focal role in creating the EE community, and so have facilitated the co-ordination of action that has enabled the complementarity among the EE taxonomy elements to flourish.

\subsection{Global focus}

As a result of the large numbers of MNE subsidiaries present in Greater Reading, the entrepreneurial ecosystem there is far more global than local. One of the apparent consequences of the global focus within the Greater Reading EE is a seeming lack of productive cooperation between entrepreneurs and other EE actors in the area, notably the region's political structures, such as the Local Economic Partnerships (LEPs) and local councils. This relatively weak support for globally-focused scale-ups slows social capital formation (Malecki, 2012) and slows entrepreneurial activity (Szerb et al., 2013). While all local government actors are, in principle, open to cooperate, the evidence is clear that they have so far failed adequately to support either smaller entrepreneurs, or high-growth start-ups and innovative start-ups. The disconnect comes down to such a basic level of which regional unit local government agents promote - Reading, as the leading city for entrepreneurial opportunities, or the Thames Valley, or the South East of England. While the evidence suggests that one of the features of the region is its poly-centric quality (not unsimilar to Greater Boston, Best, 2015), this compounds the obvious difficulty of developing a clear identity and character of a place (Feldman, 2014). The Greater Reading region EE is highly successful despite the efforts of its regional government structures.

\section{Conclusions}

A growing number of policy makers around the world are actively promoting the systemic approach to entrepreneurship policy and regional economic development (Coutu, 2014; WEF, 2014; Mason \& Brown, 2014, 2017; O'Connor et al., 2018). However, this empirical approach (Stam, 2015, 2018; Stam \& Spigel, 2016) may be dangerous when advising policymakers, as it runs ahead of its theoretical underpinnings (Acs et al., 2014; Mason \& Brown, 2017). We have applied the complementarity approach to the EE taxonomy in order to explain how those regions which possess weaknesses in some of Mason and Brown's (2017) EE taxonomy elements, may still be successful in developing EEs (Spigel, 2017; Stam, 2015).

Most regions lie outside the world's large metropolitan centres, and so almost by definition will possess weaknesses in one or more of the EE taxonomy elements. The Greater Reading region is therefore a particularly interesting case to learn about how EEs can successfully develop despite having weaknesses in one or more element. The case of Reading shows that it is possible for the stronger element to compensate for and then to complement the weaker elements. This paper contributes to better understanding how complementarity is important in the adoption of systems thinking (Cabrera et al., 2008). System thinking involves identifying 
the patterns and co-locations of contextual patterns and the relationship among the elements when the entire entrepreneurship ecosystem is in focus (Mason \& Brown, 2017).

Our study makes three key contributions to entrepreneurship ecosystem and geography of entrepreneurship literature. First, we establish that the entrepreneurship ecosystem is an alternative to business ecosystem and innovation ecosystem units of analysis (O'Connor et al., 2018) and we develop a theoretical framework focusing on complementarities in the EE taxonomy. The literature review enriches the extant literature by addressing calls to broaden the unit of analysis and system thinking beyond the boundaries of entrepreneurial firms (WEF, 2014; Martin, 2015; Stam, 2015; Autio \& Thomas, 2014; Isenberg \& Onyemah, 2016).

Second, by integrating the complementarity approach to the EE taxonomy, this study extends the foundations of entrepreneurial ecosystems in different institutional and industry environments and derives three propositions (see Section 2.2).

Third, our practical contribution is in 'testing' our argument using the case study of the Greater Reading region entrepreneurial ecosystem. In the years since the 2008 financial crisis, Reading has become the sweet-spot of economic restructuring in the UK, emerging as a highly productive region with many fast-growth scale-up firms driving the emerging tech sector. We discuss conditions, impediments and sources of competitive advantage of EE, and most importantly we demonstrate that it is the interaction of taxonomy elements that becomes important in improving performance of entrepreneurs and the region.

Based on our results, one of the interesting findings is that knowledge exploitation by highgrowth firms and small businesses takes places through a system of complementarities with contractual infrastructure and IT-enabled services (Entrepreneurial connectors). Unlike major metropolitan centres, where all elements of EE taxonomy are available, the Greater Reading region has compensated for weaknesses in the relative absence of any role-model entrepreneurial actors, and in the identity component of entrepreneurial orientation, by exploiting its strengths in other EE elements. Non-metropolitan regional capitals elsewhere around the world could follow this example of the Reading EE and concentrate on developing mechanisms and institutions to compensate for the relative weaknesses in one or more areas of the EE taxonomy and to facilitate regional economic development and support entrepreneurs locally.

Furthermore, we have shown that some actor(s) within the EE has to take the responsibility for facilitating this complementary response. Because of the ever-present tendency for market failure, this does not happen automatically. In theory this role could be undertaken by any significant local institution, and typically would be undertaken by local government. In the Greater Reading region the local government structures have been weak, and so this role has so far been performed by the University of Reading's Henley Business School. We note that this success in building the EE community and facilitating complementarity among the taxonomy elements may very well be partly because of the region's particular focus on knowledge exploitation not exploration. If a region was particularly focused on knowledge exploration, it seems unlikely that a business school could perform this community building function. 
Future research could benefit from natural experiment analysis, for example by studying two EEs within the same country and similar regulatory framework to understand to what extent regional context matters for entrepreneurial activity (Szerb et al., 2013; Qian et al., 2013; Acs et al., 2014). This will further broaden our understanding of the complementarity approach to EE taxonomy (Mason \& Brown, 2017) by identifying the contextual patterns of the organisation of the EE elements, which are place specific. Future research may also focus on in-depth discussion and conceptualisation of the framework of knowledge and entrepreneurial capital alignment within entrepreneurial ecosystem and the role of EE taxonomy elements as moderators of this process. We believe that the results are representative and generalizable not only for ecosystems like the Greater Reading region, but for other regions in the United Kingdom and for regions in developed and developing countries where entrepreneurs operate under resource constraints.

Finally, this study has implications for policy makers with regards to regional economic policy, entrepreneurship policy and higher education policy. In the UK, government funding for tech clusters and universities is strongly focused on supporting exploration and new-tomarket technologies. Our results suggest that entrepreneurial ecosystems that are focused on intermediating exploration and commercialisation of new knowledge play an important role in technology transfer and expanding knowledge frontiers for existing incumbents and slow growing small businesses. The case of the Greater Reading EE demonstrates that the placebased transformation (Stam, 2015; O'Connor et al. 2018) is not always smooth with the entrepreneur as the focus, but it includes a number of ecosystem stakeholders combining their resources, networks and capabilities in a complementary manner within and outside region boundaries. 


\section{References}

Ács, Z. J., Autio, E., \& Szerb, L. (2014), "National systems of entrepreneurship: Measurement issues and policy implications", Research Policy, 43(3), 476-494.

Anderson, C. (2015), "Reading named top in the UK for economic success for third time. The Reading Chronicle", Available at: http://www.readingchronicle.co.uk/news/13949680 (Accessed 01/11/2017)

Alvarez, S., Godley, A.C., and Wright, M. (2014) "Mark Casson, The Entrepreneur at Thirty: continued relevance?”, Strategic Entrepreneurship Journal, Vol. 8 (2), pp. 185194.

Anyadike-Danes, M., Hart, M., \& Du, J. (2015), "Firm dynamics and job creation in the United Kingdom: 1998-2013”, International Small Business Journal, Vol. 33(1), pp. 12-27.

Arrow, K. J. (1969), "Classificatory notes on the production and transmission of technological knowledge", The American Economic Review, Vol. 59(2), pp. 29-35.

Armington, C., \& Acs, Z. J. (2002), "The determinants of regional variation in new firm formation", Regional Studies, Vol. 36(1), pp. 33-45.

Audretsch, D. B., \& Feldman, M. P. (1996), "R\&D spillovers and the geography of innovation and production", The American Economic Review, Vol. 86(3), pp. 630640.

Audretsch, D. B., Keilbach, M., \& Lehmann, E. (2006), Entrepreneurship and economic growth. Oxford: Oxford University Press.

Audretsch, D. B. (2014), "From the entrepreneurial university to the university for the entrepreneurial society", The Journal of Technology Transfer, Vol. 39(3), pp. 313321.

Audretsch, D. B., Lehmann, E. E., Paleari, S., \& Vismara, S. (2016), "Entrepreneurial finance and technology transfer", The Journal of Technology Transfer, Vol. 41(1), pp. 1-9.

Audretsch, D. B., \& Lehmann, E. E. (2016), The seven secrets of Germany: Economic resilience in an era of global turbulence. Oxford: Oxford University Press.

Audretsch, D. B., \& Belitski, M. (2017), "Entrepreneurial ecosystems in cities: establishing the framework conditions", Journal of Technology Transfer, Vol. 42(5) pp. 10301051.

Autio, E., Kenney, M., Mustar, P., Siegel, D., \& Wright, M. (2014), "Entrepreneurial innovation: The importance of context", Research Policy, Vol. 43(7), pp. 10971108.

Autio, E., \& Thomas, L. D. W. (2014), "Innovation ecosystems: Implications for innovation management?". In Dodgson, M., Gann, D. M., Phillips, N. (Eds), The Oxford Handbook of Innovation Management, Oxford: Oxford University Press.

Bathelt, H., Malmberg, A., \& Maskell, P. (2004), "Clusters and knowledge: local buzz, global pipelines and the process of knowledge creation", Progress in Human Geography, Vol. 28(1), pp. 31-56.

Beckman, C. M., Hauschild, P. R. and Phillips, D. J. (2004), "Friends or strangers? Firmspecific uncertainty, market uncertainty, and network partner selection", Organization Science, Vol. 15(3), pp. 259-275.

Bengtsson, M. Kock, S. (2000). "“"Coopetition” in business Networks - to cooperate and compete simultaneously", Industrial Marketing Management, Vol. 29(5), pp. 411426.

Best, M. H. (2015), “Greater Boston's industrial ecosystem: a manufactory of sectors”, Technovation, Vol. 39-40, pp. 4-13. 
Borissenko, Y., \& Boschma, R. (2016). A critical review of entrepreneurial ecosystems: towards a future research agenda, No 1630. Section of Economic Geography: Utrecht University.

Brown, R., \& Mason, S. (2013). Scotland's companies of scale Programme. In An international benchmarking analysis of public programmes for high-growth firms (pp. 64-84). Paris: OECD.

Buenstorf, G., \& Fornahl, D. (2009), "B2C — bubble to cluster: the dot-com boom, spin-off entrepreneurship, and regional agglomeration", Journal of Evolutionary Economics, Vol. 19(3), pp. 349-378.

Casson, M.C. (1982), The Entrepreneur: An Economic Theory, Cheltenham: Edward Elgar Publishing.

Casson, M.C. and Godley, A.C. (2015) ““'Doctor, Doctor...” Entrepreneurial Diagnosis and Market Making”, Journal of Institutional Economics, Vol. 11 (3), pp. 601-621.

Centre for Cities (2017), Cities Outlook 2017, Available at: http://www.centreforcities.org/wp-content/uploads/2017/01/Cities-Outlook-2017Web.pdf (Accessed 01/11/2017)

Clarysse, B., Wright, M., Bruneel, J., \& Mahajan, A. (2014), "Creating value in ecosystems: Crossing the chasm between knowledge and business ecosystems", Research Policy, Vol. 43(7), pp. 1164-1176.

Clarysse, B., Wright, M., \& VanHove, J. (2015), “A look inside accelerators”, London: Nesta.

Choi, B., Poon, S. K. and Davis, J. G. (2008), "Effects of knowledge management strategy on organizational performance: A complementarity theory-based approach", Omega, Vol. 36(2), pp. 235-251.

Corden, A., \& Sainsbury, R. (2005), "Verbatim quotations: Whose views count?", Qualitative Research, Vol. 1(1), pp. 4-6.

Cousin, G. (2007), “Thinking with data”, Educational Developments, Issue 8.1, pp. 1-28, Available at: http://www.seda.ac.uk/resources/files/publications_16_eddev8_1.pdf (Accessed 01/11/2017).

Coutu, S. (2014), The scale-up report on UK economic growth, Available at: http://www.scaleupreport.org/scaleup-report.pdf (Accessed [Insert Date]).

Creswell, J.W., (2007), Qualitative Inquiry and Research Design: Choosing Among Five Approaches, Thousand Oaks: Sage Publications.

De Massis, A., Audretsch, D., Uhlander L., and Kammerlander N. (2017), "Innovation with limited Resources: Management Lessons from the German Mittelstand", Journal of Product Innovation Management, Vol. 35(1), pp. 125-146.

De Villiers Scheepers, M. J., Mealy, E., Clements, M., \& Lawrence, A. (2018), "Regional Entrepreneurship Ecosystems Support: South East Queensland as Case Study", In A. O’Connor, E. Stam, E., F. Sussan \& D.B. Audretsch (Eds.)., Entrepreneurial Ecosystems (pp. 1-21). Cham: Springer.

Delgado, M., Porter, M. E., \& Stern, S. (2010), “Clusters and entrepreneurship”, Journal of economic geography, Vol. 10(4), pp. 495-518.

Denzin, N. and Lincoln, Y. (2005), "The Discipline and Practice of Qualitative Research", In Denzin, N. and Lincoln, Y. (eds) The Sage Handbook of Qualitative Research. 3rd edn. Thousand Oaks, London, New Delhi: SAGE.

Etzkowitz, H., \& Leydesdorff, L. (2000), "The dynamics of innovation: from National Systems and "Mode 2" to a Triple Helix of university-industry-government relations", Research policy, Vol. 29(2), pp. 109-123.

Feld, B. (2012), Startup communities: building an entrepreneurial ecosystem in your city, New Jersey: John Wiley \& Sons. 
Feldman, M., \& Braunerhjelm, P. (2006), "The genesis of industrial clusters", In Braunerhjelm, P. \& Feldman, M. (Eds), Cluster genesis: Technology-based industrial development (pp. 1-13), Oxford: Oxford University Press.

Feldman, M., \& Zoller, T. D. (2012), "Dealmakers in place: social capital connections in regional entrepreneurial economies", Regional Studies, Vol. 46(1), pp. 23-37.

Feldman, M. P. (2014), "The character of innovative places: entrepreneurial strategy, economic development, and prosperity", Small Business Economics, Vol. 43(1), pp. 9-20.

Fujita, M., Krugman, P. R., \& Venables, A. (2001), The spatial economy: cities, regions, and international trade, MA: MIT Press.

Garnsey, E., \& Heffernan, P. (2005), "High-technology clustering through spin-out and attraction: The Cambridge case", Regional Studies, Vol. 39(8), pp. 1127-1144.

Gertler, M. S. (2010), "Rules of the game: the place of institutions in regional economic change", Regional Studies, Vol. 44(1), pp. 1-15.

Granovetter, M. S. (1973), "The strength of weak ties", American Journal of Sociology, Vol. 78(6), pp. 1360-1380.

HCFE (2017), Henley Centre for Entrepreneurship Newsletter 3, 2017. Available at: https://www.henley.ac.uk/research/research-centres/henley-centre-forentrepreneurship/ (Accessed 02/05/2018).

Isenberg, D. (2011), "The entrepreneurship ecosystem strategy as a new paradigm for economic policy: Principles for cultivating entrepreneurship", Presentation at the Institute of International and European Affairs.

Isenberg, D., \& Onyemah, V. (2016), "Fostering scaleup ecosystems for regional economic growth", Innovations, Vol. 11(1-2), pp. 60-79.

Kemeny, T., Feldman, M., Ethridge, F., \& Zoller, T. (2015), “The economic value of local social networks", Journal of Economic Geography, Vol. 16(5), pp. 1101-1122.

Klepper, S. (2010), "The origin and growth of industry clusters: The making of Silicon Valley and Detroit", Journal of Urban Economics, Vol. 67(1), pp. 15-32.

Kirzner, I. M. (1999), "Creativity and/or alertness: A reconsideration of the Schumpeterian entrepreneur", The Review of Austrian Economics, Vol. 11(1-2), pp. 5-17.

KPMG (2015) UK Tech Monitor. Available at: https://assets.kpmg.com/content/dam/kpmg/pdf/2015/12/tech-monitor-december2015.pdf (Accessed 01/11/2017).

Lee, C.-H., Venkatraman, N., Tanriverdi, H. and Iyer, B. (2010), "Complementarity-based hypercompetition in the software industry: theory and empirical test, 1990-2002", Strategic Management Journal, Vol. 31(13), pp. 1431-1456.

Lee, N. (2014), "What holds back high-growth firms? Evidence from UK SMEs. Small Business Economics", Vol. 43(1), pp. 183-195.

Leten, B., Vanhaverbeke, W., Roijakkers, N., Clerix, A. and Van Helleputte, J. (2013), "IP Models to Orchestrate Innovation Ecosystems", California Management Review, Vol. 55(4), pp. 51-64.

Li, W., Liu, K., Belitski, M., Ghobadian, A., O'Regan, N. (2016), “e-Leadership through strategic alignment: an empirical study of small-and medium-sized enterprises in the digital age", Journal of Information Technology, Vol. 31(2), pp. 185-206.

Malecki, E. J. (2012), "Regional social capital: why it matters", Regional Studies, Vol. 46(8), pp. 1023-1039.

Marshall, A. (1890), Principles of Economics, London: Macmillan.

March, J.G. (1991), "Exploration and exploitation in organizational learning", Organization Science, Vol. 2(1), pp. 71-87. 
Martin, R., \& Sunley, P. (2011), "Conceptualizing cluster evolution: beyond the life cycle model?", Regional Studies, Vol. 45(10), pp. 1299-1318.

Martin, R. (2015), "Rebalancing the spatial economy: the challenge for regional theory", Territory, Politics, Governance, Vol. 3(3), pp. 235-272.

Markusen, A. (1996), "Sticky places in slippery space: a typology of industrial districts", Economic Geography, Vol. 72(3), pp. 293-313.

Mason, C., \& Brown, R. (2014), "Entrepreneurial ecosystems and growth oriented entrepreneurship", Final Report to OECD, Paris, pp. 1-38.

Mason, C., \& Brown, R. (2017), "Looking inside the spiky bits: a critical review and conceptualisation of entrepreneurial ecosystems", Small Bus Econ, Vol. 49(1), pp. $11-30$.

Mayer, H. (2013), "Entrepreneurship in a hub-and-spoke industrial district: Firm survey evidence from Seattle's technology industry", Regional Studies, Vol. 47(10), pp. 1715-1733.

Miller, P., \& Bound, K. (2011), The Startup Factories, London: NESTA.

Nambisan, S., \& Baron, R. A. (2013), "Entrepreneurship in innovation ecosystems: entrepreneurs' self-regulatory processes and their implications for new venture success", Entrepreneurship Theory and Practice, Vol. 37(5), pp. 1071-1097.

Napier, G., \& Hansen, C. (2011), Ecosystems for Young Scaleable Firms, Cophehagen: FORA Group.

O’Connor, A., Stam, E., Sussan, F., \& Audretsch, D. B. (2018), "Entrepreneurial Ecosystems: The Foundations of Place-based Renewal”, In A. O'Connor, E. Stam, E., F. Sussan \& D.B. Audretsch (Eds.), Entrepreneurial Ecosystems (pp. 1-21), Cham: Springer.

Parmigiani, A. and Mitchell, W. (2009), "Complementarity, capabilities, and the boundaries of the firm: the impact of within-firm and interfirm expertise on concurrent sourcing of complementary components", Strategic Management Journal, Vol. 30(10), pp. 1065-1091.

Pierce, L. (2009), "Big losses in ecosystem niches: how core firm decisions drive complementary product shakeouts", Strategic Management Journal, Vol. 30(3), pp. 323-347.

Porter, M. E. (2000), "Location, competition, and economic development: local clusters in a global economy", Economic Development Quarterly, Vol. 14(1), pp. 15-34.

Porter, M. and Siggelkow, N. (2008), "Contextuality within activity systems and sustainability of competitive advantage", Academy of Management Perspectives, Vol. 22(2), pp. 34-56.

Qian, H., Acs, Z. J., \& Stough, R. R. (2013), "Regional systems of entrepreneurship: the nexus of human capital, knowledge and new firm formation", Journal of Economic Geography, Vol. 13(4), pp. 559-587.

The Business Magazine (2017), Reading Number 1 City Report. Available at: http://readingnumber1city.co.uk (Accessed 01/11/2017).

Rogerson, S (2016), "High growth Small business Urban hub league Table 2016", Octopus Investments. Available at: http://www.scaleupinstitute.org.uk/wpcontent/uploads/2016/03 (Accessed 01/11/2017).

Saxenian, A. (1996), Regional Advantage: Culture and Competition in Silicon Valley and Route 128, CA: Harvard University Press.

Spigel, B. (2017), "The relational organization of entrepreneurial ecosystems", Entrepreneurship Theory and Practice, Vol. 41(1), pp. 49-72.

Stangler, D. and Bell-Masterson, J. (2015), "Measuring an entrepreneurial ecosystem", Kauffman Foundation. March 2015 Ed. 
Stam, E. (2007), "Why butterflies don't leave: locational behavior of entrepreneurial firms. Economic Geography”, Vol. 83(1), pp. 27-50.

Stam, E. (2015), "Entrepreneurial ecosystems and regional policy: a sympathetic critique", European Planning Studies, Vol. 23(9), pp. 1759-1769.

Stam, F. C., Spigel, B. (2016). Entrepreneurial ecosystems. USE Discussion Paper Series, nr. 16-13.

Stam, E (2018), “Measuring Entrepreneurial Ecosystems”, In A. O’Connor, E. Stam, E., F. Sussan \& D.B. Audretsch (Eds.), Entrepreneurial Ecosystems (pp. 173-197). Cham: Springer.

Sussan, F., Sloboda, B., \& Hall, R. (2018), "Is there a path from sin city to tech city? The case for Las Vegas”, In A. O’Connor, E. Stam, E., F. Sussan \& D.B. Audretsch (Eds.), Entrepreneurial Ecosystems (pp. 173-197), Cham: Springer.

Szerb, L., Acs, Z. J., Autio, E., Ortega-Argilés, R., \& Komlósi, É. (2014), REDI: The Regional Entrepreneurship and Development Index-Measuring regional entrepreneurship Report for the European Commission Directorate-General Regional and Urban Policy under contract number 2012.

Thames Valley Berkshire (TVB) (2014), Delivering national growth, locally, Strategic Economic Plan, 2015/16 - 2020/21 - The Evidence Base, 2014 Report.

Van der Panne, G. (2004), “Agglomeration externalities: Marshall versus Jacobs", Journal of Evolutionary Economics, Vol. 14(5), pp. 593-604.

WEF. (2014), Entrepreneurial ecosystems and around the globe and early-stage company growth dynamics - an entrepreneurs perspective. Davos: World Economic Forum available at http://www3.weforum.org/docs (Accessed 01/11/2017).

Welter, F., Baker, T., Audretsch, D. B., \& Gartner, W. B. (2017), "Everyday entrepreneurship - a call for entrepreneurship research to embrace entrepreneurial diversity", Entrepreneurship Theory and Practice. Vol. 41(3), pp. 311-321.

Williamson, P. and De Meyer, A. (2012), "Ecosystem advantage: how to successfully harness the power of partners", California Management Review, Vol. 55(1), pp. 24-46.

$\mathrm{Wu}, \mathrm{B}$., Wan, Z. and Levinthal, D. A. (2014), "Complementary assets as pipes and prisms: innovation incentives and trajectory choices", Strategic Management Journal, Vol. 35(9), pp. 1257-1278. 


\section{Appendix A}

Interview protocol "Entrepreneurship Ecosystem taxonomy framework"

\begin{tabular}{|c|c|c|c|}
\hline Questions & $\begin{array}{l}\text { EE } \\
\text { Taxonomy } \\
\text { element }\end{array}$ & Indicative reason & $\begin{array}{l}\text { Justification from } \\
\text { the literature / study } \\
\text { objective }\end{array}$ \\
\hline $\begin{array}{l}\text { How has your location in the } \\
\text { Thames Valley been of } \\
\text { influence for your business? }\end{array}$ & $\mathrm{O}$ & $\begin{array}{l}\text { Broad answer expected } \\
\text { for analysis. Might } \\
\text { include EE elements. }\end{array}$ & $\begin{array}{l}\text { Economy of place } \\
\text { literature. }\end{array}$ \\
\hline $\begin{array}{l}\text { How has the presence of other } \\
\text { businesses in the Thames } \\
\text { Valley influenced you and your } \\
\text { business? Any role models? }\end{array}$ & $\mathrm{A}$ & & $\begin{array}{l}\text { A show of EE } \\
\text { element interaction. } \\
\text { Role model question } \\
\text { targeted as per } \\
\text { argument in the paper }\end{array}$ \\
\hline $\begin{array}{l}\text { Are there any opportunities you } \\
\text { think are available to you per } \\
\text { your location? } \\
\text { [proximity to London?] }\end{array}$ & $\mathrm{R}$ & $\begin{array}{l}\text { Broad answer expected } \\
\text { for analysis. Other EE } \\
\text { elements to be mined } \\
\text { from this data. }\end{array}$ & $\begin{array}{l}\text { Mason \& Brown } \\
(2014) \\
\text { Proximity to London } \\
\text { would justify one of } \\
\text { our arguments. }\end{array}$ \\
\hline $\begin{array}{l}\text { Do you have any limitations or } \\
\text { barriers that you ascribe to your } \\
\text { location? }\end{array}$ & & $\begin{array}{l}\text { Answers here to show } \\
\text { presence/absence of } \\
\text { some components of } \\
\text { EE }\end{array}$ & $\begin{array}{l}\text { Paper's objective; we } \\
\text { argue that not all EE } \\
\text { components must } \\
\text { necessarily be present }\end{array}$ \\
\hline $\begin{array}{l}\text { How would you compare the } \\
\text { Reading entrepreneurial } \\
\text { mindset to the Silicon Valley } \\
\text { mindset? Why (not)? }\end{array}$ & $\mathrm{O}$ & & $\begin{array}{l}\text { For entrepreneurial } \\
\text { orientation element. }\end{array}$ \\
\hline $\begin{array}{l}\text { What would make you NOT } \\
\text { want to move away from the } \\
\text { Thames Valley location? }\end{array}$ & All & $\begin{array}{l}\text { Answers here expected } \\
\text { to shed light on the } \\
\text { complementarity } \\
\text { perspective if any. }\end{array}$ & Paper's objective. \\
\hline $\begin{array}{l}\text { How would you describe the } \\
\text { ability to find resources (could } \\
\text { be financial) in the Thames } \\
\text { region? }\end{array}$ & $\mathrm{R}$ & & $\begin{array}{l}\text { Addresses one } \\
\text { element of the EE; } \\
\text { resource providers. }\end{array}$ \\
\hline $\begin{array}{l}\text { How would you describe the } \\
\text { role of Henley Business School } \\
\text { in the Thames Valley for your } \\
\text { business? } \\
\text { Or of other institutions for your } \\
\text { business? }\end{array}$ & $\mathrm{C}$ & & $\begin{array}{l}\text { Ditto. } \\
\text { A show of EE } \\
\text { element interaction } \\
\text { Addresses } \\
\text { entrepreneurial } \\
\text { connectors element. }\end{array}$ \\
\hline $\begin{array}{l}\text { What do you think about the } \\
\text { general performance of } \\
\text { businesses co-located in the } \\
\text { Thames Valley? Why? }\end{array}$ & $\mathrm{A}+\mathrm{C}$ & $\begin{array}{l}\text { Intended to allow us } \\
\text { mine the data on } \\
\text { complementarity; a } \\
\text { spin on question } 2 \text {. }\end{array}$ & Paper's objective. \\
\hline
\end{tabular}

Note: $\mathrm{C}=$ connectors; $\mathrm{A}=$ actors; $\mathrm{R}=$ resource; $\mathrm{O}=$ orientation

Source: Authors. 


\section{Appendix B}

\section{List of Study Participants}

\begin{tabular}{|c|c|c|c|}
\hline $\begin{array}{c}\text { Region/Country/Name } \\
\text { of Scale-Up }\end{array}$ & Core products/services & Sector & $\begin{array}{l}\text { Interview } \\
\text { role }\end{array}$ \\
\hline $\begin{array}{c}\text { Greater } \\
\text { Reading/UK/Kymira }\end{array}$ & Advanced sportswear & Sports & $\begin{array}{l}\text { Founder \& } \\
\text { CEO }\end{array}$ \\
\hline $\begin{array}{c}\text { Greater } \\
\text { Reading/UK/Rotolight }\end{array}$ & $\begin{array}{l}\text { Advanced LED lighting } \\
\text { technology system }\end{array}$ & Technology & $\begin{array}{l}\text { Founder \& } \\
\text { CEO }\end{array}$ \\
\hline $\begin{array}{c}\text { Greater } \\
\text { Reading/UK/Ecrebo }\end{array}$ & IT services & Software & HR Manager \\
\hline $\begin{array}{c}\text { Greater } \\
\text { Reading/UK/Rdg1 }\end{array}$ & Financial services & Finance & CTO \\
\hline $\begin{array}{c}\text { Greater } \\
\text { Reading/UK/Rdg2 }\end{array}$ & Business consultancy services & IT consulting & $\begin{array}{l}\text { Founder \& } \\
\text { MD }\end{array}$ \\
\hline $\begin{array}{c}\text { Greater } \\
\text { Reading/UK/Rdg3 } \\
\end{array}$ & Business consultancy services & IT consulting & Co-Founder \\
\hline $\begin{array}{c}\text { Greater } \\
\text { Reading/UK/Henley } \\
\text { Business School /Rdg6 }\end{array}$ & Tertiary Education & Higher Education & $\begin{array}{l}\text { Executive } \\
\text { Director }\end{array}$ \\
\hline $\begin{array}{c}\text { Paddy Radcliffe/ } \\
\text { Telios partners/ } \\
\text { Reading }\end{array}$ & Business consultancy services & Knowledge services & Co-director \\
\hline $\begin{array}{l}\text { Melvyn Lloyd / Edge } \\
\text { Plus Global Ltd/ } \\
\text { Reading }\end{array}$ & $\begin{array}{l}\text { Human resource apps for } \\
\text { improving work efficiency }\end{array}$ & Human Resources & $\mathrm{CEO}$ \\
\hline $\begin{array}{c}\text { Andrew Humphreys / } \\
\text { The improvement } \\
\text { agency/Reading }\end{array}$ & Social and welfare services & Social & CEO \\
\hline $\begin{array}{c}\text { Chris Cragg/ } \\
\text { MCFT/Reading }\end{array}$ & $\begin{array}{c}\text { Commercial industrial and } \\
\text { kitchen equipment maintenance }\end{array}$ & High-tech services & $\mathrm{CEO}$ \\
\hline
\end{tabular}

Note: Companies tagged Rdg* do not wish to be disclosed. 